\title{
EXPLORING BENEFITS AND CHALLENGES OF USING BLACKBOARD COLLABORATE AS A REMOTE LEARNING TOOL AMONG QASSIM UNIVERSITY EFL INTENSIVE COURSE PROGRAM STUDENTS DURING COVID-19 PANDEMIC
}

\author{
Mustafa Mohammed Sadek Elsayed \\ Dr. Department of English Language and Translation, College of Science and Arts in Unaizah, \\ Qassim University, Saudi Arabia, mustafasadek2000@gmail.com
}

\begin{abstract}
Due to the outbreak of COVID-19 pandemic, using Blackboard platform as a learning tool has dramatically increased in Saudi universities. Still, learners lack effective knowledge of using Blackboard platform. Accordingly, there is a pressing need to concentrate on using Blackboard platform during the COVID-19 pandemic to improve learning outcomes. Therefore, this study was conducted to explore the benefits and challenges of using Blackboard Collaborate as a learning tool by EFL ICP students during the COVID-19 pandemic. Focus group interviews were used to collect data from a purposive sample of 15 Saudi male ICP students who took part willingly in this study. Inductive thematic analysis was used to analyze the interview data. The findings showed that using Blackboard Collaborate as a learning tool can help the students enhance online cooperative learning, flexible learning in a variety of ways other than traditional classes, having access to a wide range of information for academic purposes and ability to use technology effectively. Additionally, the findings showed that the challenges faced by ICP students include insufficient technical knowledge and training, limited and poor internet connection, inability to upload and download large size files and problems with logging in password. It was intended that this research would be useful to all higher education institutions stakeholders in general. However, with only a few participants, this study was limited to EFL ICP students at Qassim University. Further research may use a quantitative or mixed-method approach to provide generalizable results.
\end{abstract}

Keywords: EFL Intensive Course Program, Blackboard Collaborate, COVID-19 Pandemic

\section{INTRODUCTION}

On March 8, 2020, three days before the World Health Organization (WHO) declared Covid-19 a pandemic (World Health Organization, 2020), Saudi Arabia closed all schools, colleges, and universities (Saudi Press Agency 2020). The Ministry of Education has ordered all educational institutions to switch to synchronous and asynchronous distant learning as soon as possible. Distance learning was mandated for all educational institutions. According to a UNESCO report, 8,410,264 students in Saudi Arabia were affected, with $1,620,491$ of them in tertiary education (UNESCO, 2020). Luckily, almost all public universities in Saudi Arabia have ICT infrastructure since the beginning of the millennium (Al-Asmari \& Rabb Khan, 2014). At the 
time of the closure of Saudi Arabia's higher education institutions, all of the public universities had adopted Blackboard as their major learning management system (LMS) (Al-Nofaie, 2020).

Up till now, all countries worldwide are still struggling to overcome the unexpected negative impacts of the COVID-19 and until effective drugs are discovered, the best protection measurements are still social distancing. To this end, Saudi universities used different online modes to teach their students. E-learning is already implemented in most of the Saudi higher-educational institutions (Muhammad et al., 2020). Many Saudi universities have integrated Learning Management System (LMS) as a learning tool in a variety of specializations. It was adopted in Saudi universities due to its accessibility, ubiquity, and ease of integration with traditional classroom instruction. Blackboard software, which is used in many Saudi universities, is one of the most well-known forms of the LMS. Blackboard is defined as "one of the leading commercial learning management systems (LMS) software packages used in universities in North America and Europe" (Munoz \& Van Duzer, 2005). Additionally, and as mentioned on the Blackboard website, "The Blackboard Learning System is a world-class software application for institutions dedicated to teaching and learning. Intuitive and easy-to-use, this product has powerful capabilities in three key areas: Instruction, Communication and Assessment" (Blackboard, n.d, para. 1). Similarly, Heirdsfield et al. (2011) stated that blackboard is referred to as a software package developed to assist educationalists in creating quality oriented online courses. Ibrahim et al. (2019) found that this software has numerous features which can foster teaching and learning. It is the easiest mode of promoting the interaction among teachers and students.

Generally speaking, Blackboard has many benefits for both learners and teachers. For learners, one of the key benefits of Blackboard is that it offers diverse ways to involve learners outside of the conventional classroom. The use of distant tools in this software devised for the learners to approach the learning material and a platform of interaction (Jacob \& Issac, 2008; Kitoo, 2020). In addition, it allows learners to take part in the live discussion with the group members, submit their homework and assignment and track their progress on their own. For teachers, Blackboard helps them develop flexible course content, build discussion forums and interactive assignments, create and administrate the exams effectively. Furthermore, it provides a good mechanism for keeping track of all of the teachers' and students' quizzes, tests, and emails. EFL ICP is a university preparatory program based on an academic EFL syllabus including Grammar, Vocabulary, Reading, Writing, Listening and Speaking, and designed to sharpen Secondary School leavers' English language skills in order to excel in the challenge of higher education in Saudi Arabia. Despite the many benefits of using Blackboard Collaborate as a learning platform, Qassim University EFL ICP students are instantly confronted with an online learning system that is vastly different from the face-to-face traditional instruction to which they get used, both technologically and educationally. As a result, students may experience challenges in adjusting to the new online learning environment and the new online examination standards. Given this overall context, the study focuses on exploring benefits and challenges of using Blackboard Collaborate as a remote learning tool among Qassim University EFL ICP students during COVID-19 pandemic.

\section{LITERATURE REVIEW}

One of the online interactive learning tools available to learners and their higher education institutions during the outbreak of COVID-19 pandemic is Blackboard Collaborate. Blackboard is one of the major prevalent Learning Management Systems adopted by universities (Chang 2008). Blackboard is defined as "software package designed to help educators create quality online courses" (Choy et al. 2005, p. 130). Khafaga (2021) stated that due to its universality, ease of use and availability, almost all Saudi higher education institutions adopted the Blackboard Collaborate as one of the most common used digital platforms during COVID-19 pandemic. The use of virtual classrooms is becoming more common, and digital platforms like Blackboard Collaborate-based instruction are becoming more popular (Khafaga, 2021). This was emphasized by Mohsen and Shafeeq (2014), who confirmed that Blackboard Collaborate is one of the digital platforms for blended learning that allows students and teachers to communicate with one another. They also maintained that Blackboard Collaborate has become one of the emergent educational technologies that are broadly used by numerous higher educational institutions not only in Saudi Arabia, but worldwide as well.

According to Mohsen and Shafeeq (2014), Blackboard is a digital platform that offers a type of an online learning atmosphere that helps students and teachers to attend their virtual classes, download their assignments, involve in an online discussion, get in-time feedback, and sit for their examinations. The different elements of the learning process, which include simple access to course material, assignments, discussions, and so on, are all represented by this sort of digital communication via Blackboard. Learners can work independently and in groups utilizing the Blackboard system. Because Blackboard Collaborate provides so many alternatives for online learning and teaching, the learning process has become more 
flexible. All educational tasks can easily be fulfilled within Blackboard Collaborate which strengthens the mutual relationship between the so many parts of the learning process, namely, teachers, learners, and courses (Mohsen, \& Shafeeq, 2014). Farooq, Alasmari and Javid (2012) added that Blackboard-based instruction guarantees a more flexible and equal participation in the learning process. Additionally, Blackboard provides faculty members with useful tools for managing course content in a flexible manner. It enables them to create electronic interactive courses and manage duties such as presentations, assignments, quizzes, tests, scores, grades, course outline, and email sending and receiving, in addition to announcements to students. Additionally, it enables faculty members to divide their students into groups, follow up them via tracking the number of times of their access and manage live chat with them. Moreover, Martin, Parker \& Oyarzun, (2013) claimed that, unlike traditional instruction, where participation in classrooms may be limited to only two or three students, Blackboard-based instruction allows all students in the same virtual class to participate in discussions in a controlled and satisfactory manner. Participants are monitored, directed, and called for discussion. As Adams Becker et al. (2017) advocate, Blackboard Collaborate is a web-conferencing or synchronous collaborative online teaching tool that is browser-based, and therefore, does not require any installation. Instead, when setting up a session, a link is generated that can then be provided to participants to access. Sessions can also be recorded and viewed at a later date to provide additional flexibility and convenience for students. The user-friendly interface of Blackboard Collaborate allows faculty members to use it for a variety of online teaching methods, including lectures, seminars, tutorials, and drop-in sessions.

When applied to the teaching of EFL at Najran University in the Kingdom of Saudi Arabia, Mohsen and Shafeeq (2014) claimed that Blackboard-based instruction has very positive effects. They found out in their research that applying Blackboard-based instruction helps both learners and teachers affiliated with Najran University maintain a positive academic relationship, which in turn facilitates the entire process of teaching English courses at the department of English at various academic levels. Their research also revealed that teachers regard Blackboard as a well-structured and well-organized digital platform that aids in the learning/teaching process. In another study conducted on students and teachers at King Khalid University in Saudi Arabia, Alzahour (2013) suggested that blended learning in general and Blackboard-based learning in particular help students enhance their reading skills and expand their vocabulary. This study showed how successful Blackboard-based instruction can be at the university level. It also demonstrated that this digital platform provides participants with a variety of online options that are beneficial in EFL classes, notably reading and vocabulary. A further study conducted by Kashghari and Asseel (2014) at King Abdul Aziz University illustrated the positive contribution and the benefits of utilizing Blackboard to improve students' listening skills. Their study also stressed that Blackboard-based instruction is effective in enhancing listening skill more than any other language skills. When it comes to the utilization of Blackboard-based learning by male and female students, Almaqtri (2014) observed a gender gap between them. Almaqtri claimed that using a digital learning platform resulted in female students expressing more positive attitudes than their male counterparts. The study further pointed out that students faced some challenges when they use Blackboard-based learning. Some of these challenges are the result of technical reasons, while others are the result of some cultural, academic and even economic factors. Although the Learning Management Systems have sped up the transition to emergency online learning, various challenges have arisen, including the bandwidth issues and the Internet speed, especially in remote areas, and availability of laptops and tablets to students (AlHazizi, 2020). Other technical problems are linked directly to the Blackboard platform itself, namely the synchronous learning (Alkarani \& Al Thobaity, 2020).

\section{RESEARCH QUESTIONS}

The purpose of this study is to explore the benefits and challenges of using Blackboard Collaborate as a learning tool during Covid-19 pandemic as perceived by ICP students. More specifically, the study seeks to respond to the following questions in relation to ICP students' experience with using Blackboard Collaborate as a remote learning tool during the first few weeks of the shift from face-to-face learning to online learning in the context of the COVID-19 pandemic:

RQ1: What are the benefits of using Blackboard Collaborate as a remote learning tool during Covid-19 pandemic as perceived by ICP students?

RQ2: What are the challenges of using Blackboard Collaborate as a remote learning tool during Covid-19 pandemic as perceived by ICP students?

\section{SIGNIFICANE OF THE STUDY}

The current study's significance stems from its endeavor to shed light on the benefits and challenges of 
using Blackboard Collaborate as a remote learning tool during the COVID-19 epidemic. As a result, the study is expected to provide a theoretical and pedagogical contribution to the field of EFL learning. Theoretically, it strives to shed light on the incorporation of developing technologies in the learning process; pedagogically, it emphasizes the effective contribution of using modern technology tools of learning on learning outcomes.

\section{RESEARCH METHODOLOGY}

\subsection{Context of the Study}

This study was conducted in the second semester of 2020 academic year, after students completed their online courses and during their personal attendance of the final exams. This study applied a qualitative method in which focus group interviews were utilized to explore the benefits and challenges of using Blackboard Collaborate as a remote learning tool during Covid-19 pandemic. Focus group interviews, according to Jackson (1998), are flexible and relatively easy to conduct. A wide range of themes can be attained via focus group interviews as comments from one participant may generate responses from others (McLafferty, 2004; Jackson, 1998).

\subsection{Participants}

The purposive sample of this study included 15 EFL ICP students of College of Science and Arts in Unaizah, Qssim University, Saudi Arabia. In general, 15 participants are sufficient for focus group interviews (Goss \& Leinbach, 1996). The participants' ages range from 16 to 18. They have been learning EFL for more than 8 years. Due to the outbreak of COVID-19 Pandemic and the shift from face to face learning to online learning, most of them had to be trained online in using Blackboard Collaborate by Qassim University Deanship of E-Learning and Distance Learning. The data was collected by the author of this study who is the coordinator and tutor of the ICP students. Based on the students' interest to participate in the study, the 15 participants were selected.

\subsection{Instrumentation}

According to Creswell (2012), semi-structured interviews generate information that might not be expected by the researchers. To collect data from the participants, semi-structured interviews were used. The interviews included predetermined questions that focus on the benefits and challenges of using Blackboard Collaborate as a remote learning tool during COVID-19 pandemic. The interviews were conducted face-to-face with the 15 participants. According to O'Reilly (2005), interviews are considered powerful tools for information gathering as participants are allowed to express their views freely on a specific topic (O'Reilly, 2005). Fifteen ICP students were given the opportunity to express their opinions, perceptions and attitudes frankly and orally. The semi-structured interview questions focused on ICP students' perceptions in regard with the benefits and challenges of using Blackboard Collaborate as a learning tool during COVID-19 pandemic. Participants expressed their perspectives on the benefits and challenges of using Blackboard Collaborate as a remote learning tool during the pandemic, its contributions to developing students' language skills, and practical difficulties to effective Blackboard integration in learning English language courses during the COVID-19 pandemic.

\subsection{Data Analysis}

Inductive thematic analysis was used to analyze the interview data. Cohen, Manion, and Morrison (2007) proposed four stages for doing the analysis: Generating natural units of meaning; labeling, categorizing, and ordering the natural units; constructing narratives; and interpretation. In contrast to numerical analysis, Cohen et al. (2007) emphasized that qualitative analysis is certainly interpretive. The coding process consisted of reading through the interview data, identifying, categorizing, and interpreting themes based on the participants' responses.

\section{FINDINGS OF THE RESEARCH}

The purpose of this study was to explore the ICP students' perceptions in regard with the benefits and challenges of using Blackboard Collaborate as a remote learning tool during COVID-19 pandemic at College of Science and Arts in Unaizah, Qassim University, Saudi Arabia. The fifteen participants were asked to give their thoughts on the benefits and challenges of using Blackboard Collaborate as a remote learning tool during the COVID-19 pandemic. The aim of the first question was to identify the benefits of using Blackboard Collaborate as a remote learning tool during the COVID-19 pandemic. This information is illustrated in Table 1 as follows. 
Table1. Benefits of using Blackboard Collaborate as a remote learning tool during the COVID-19 pandemic

\begin{tabular}{|c|c|c|}
\hline Interview Questions & Themes & Exemplary quotes \\
\hline \multirow[t]{2}{*}{$\begin{array}{l}\text { Based on your experience as } \\
\text { an Intensive Course Program } \\
\text { student, what benefits do you } \\
\text { obtain from using Blackboard } \\
\text { Collaborate as a remote } \\
\text { learning tool during the } \\
\text { COVID-19 pandemic? }\end{array}$} & Online cooperative learning & $\begin{array}{l}\text {...based on my experience with } \\
\text { using blackboard, I could say that } \\
\text { it's now much easier for me to } \\
\text { learn and work together with my } \\
\text { classmates and communicate with } \\
\text { my instructors simultaneously } \\
\text { (P11) }\end{array}$ \\
\hline & $\begin{array}{l}\text { Flexible learning in a variety of } \\
\text { ways other than face to face } \\
\text { learning }\end{array}$ & $\begin{array}{l}\text {...using Blackboard makes me } \\
\text { feel like a flexible learner (P9) ... } \\
\text { using Blackboard has made my } \\
\text { learning flexible (P3) ...using } \\
\text { Blackboard allows me to present } \\
\text { my assignment flexibly (P6) }\end{array}$ \\
\hline \multirow[t]{2}{*}{$\begin{array}{l}\text { What other benefits do you } \\
\text { obtain from using Blackboard } \\
\text { Collaborate as a remote } \\
\text { learning tool in general? }\end{array}$} & $\begin{array}{l}\text { Having access to a wide range of } \\
\text { information for academic } \\
\text { purposes }\end{array}$ & $\begin{array}{l}\text {...using Blackboard is very useful } \\
\text { as I can access a wide range of } \\
\text { information. (P8) ..... a lot of } \\
\text { information can be accessed } \\
\text { through using Blackboard based } \\
\text { content (P7) }\end{array}$ \\
\hline & $\begin{array}{l}\text { Ability to use technology } \\
\text { effectively }\end{array}$ & $\begin{array}{l}\text {...as a result of using blackboard, } \\
\text { I learnt how to make use and } \\
\text { access online materials for doing } \\
\text { my assignments (P2) } \\
\text {...by using Blackboard, I gain a } \\
\text { better understanding of new } \\
\text { technology (P3) ...using } \\
\text { blackboard helps me improve my } \\
\text { online communication skills (P4) }\end{array}$ \\
\hline
\end{tabular}

Note: $\mathrm{P}=$ Participants

As shown in Table 1, the emergent themes suggest that using Blackboard Collaborate can help ICP students enhance online cooperative learning and flexible learning in a variety of ways other than face to face learning. In addition, the students believe that Blackboard Collaborate provides an easy access to a wide range of information for academic purposes. They also believe that using Blackboard Collaborate helps them develop their ability to use technology effectively. These findings show that, despite some challenges, students still appreciate and benefit from utilizing Blackboard Collaborate as a remote learning tool throughout the COVID-19 pandemic. The aim of the second question was to identify the challenges of using Blackboard Collaborate as a remote learning tool during the COVID-19 pandemic. This information is illustrated in Table 2 as follows. 
Table 2. Challenges of using Blackboard Collaborate as a remote learning tool during the COVID-19 pandemic

\begin{tabular}{|c|c|c|}
\hline Interview Questions & Themes & Exemplary quotes \\
\hline \multirow[t]{4}{*}{$\begin{array}{l}\text { Based on your experience } \\
\text { as an Intensive Course } \\
\text { Program student, what } \\
\text { challenges do you } \\
\text { encounter when using } \\
\text { Blackboard Collaborate as a } \\
\text { remote learning tool during } \\
\text { the COVID-19 pandemic? }\end{array}$} & $\begin{array}{l}\text { Insufficient technical knowledge } \\
\text { and training }\end{array}$ & $\begin{array}{l}\ldots \text { I have never used the } \\
\text { Blackboard platform before at my } \\
\text { secondary school (P12) ...I } \\
\text { didn't have a Blackboard platform } \\
\text { while I was a student in secondary } \\
\text { school (P1) ...I have never } \\
\text { used Blackboard platform during } \\
\text { my previous study years (P15) }\end{array}$ \\
\hline & $\begin{array}{l}\text { Limited and poor internet } \\
\text { connection }\end{array}$ & $\begin{array}{l}\text {...the internet was really slow, and } \\
\text { I was frequently interrupted and } \\
\text { logged out during many study } \\
\text { sessions (P5) ....the } \\
\text { internet connection was frequently } \\
\text { interrupted... (P10) ... during my } \\
\text { course, I was in a hard need of a } \\
\text { good internet connection... (P13) } \\
\ldots \text {..the main challenge I had was } \\
\text { the lack of good internet } \\
\text { connection (P14) }\end{array}$ \\
\hline & $\begin{array}{l}\text { Inability to upload and download } \\
\text { large size files }\end{array}$ & $\begin{array}{l}\text { Well...I had difficulty uploading } \\
\text { and downloading large size } \\
\text { files...(P11) ... had a } \\
\text { problem with uploading and } \\
\text { downloading some files which } \\
\text { exceeded maximum size(P13) }\end{array}$ \\
\hline & $\begin{array}{l}\text { Problems with logging in } \\
\text { password }\end{array}$ & $\begin{array}{l}\text { Yes, I had a problem with my } \\
\text { password... (P 3) } \\
\text { the password I was given did not } \\
\text { work properly all the time....(P9) }\end{array}$ \\
\hline \multirow[t]{2}{*}{$\begin{array}{l}\text { What can be done to } \\
\text { overcome these } \\
\text { challenges? }\end{array}$} & $\begin{array}{l}\text { Training on using Blackboard } \\
\text { platform and technical orientations }\end{array}$ & $\begin{array}{l}\text { In my point of view, the university } \\
\text { should organize more } \\
\text { technological training courses and } \\
\text { more orientation programs for ICP } \\
\text { new students (P1) ...I think } \\
\text { there should be more training } \\
\text { courses on using Blackboard } \\
\text { platform associated with technical } \\
\text { orientations (P10)...I believe that } \\
\text { most of ICP students need to be } \\
\text { trained more and more on using } \\
\text { Blackboard platform (P14) } \\
\text { In my view, all ICP students are in } \\
\text { hard need to be technically trained } \\
\text { and oriented (P12) }\end{array}$ \\
\hline & $\begin{array}{l}\text { Providing stable and fast internet } \\
\text { connection }\end{array}$ & $\begin{array}{l}\ldots . \text { think that the internet } \\
\text { connection needs to be stable and } \\
\text { fast }(P 9) \quad \ldots \text { students can } \\
\text { get rid of stress during their }\end{array}$ \\
\hline
\end{tabular}




\begin{tabular}{|l|l|l|}
\hline & $\begin{array}{l}\text { Blackboard sessions if there were } \\
\text { a faster internet connection (P13) } \\
\ldots \text {. believe that speed and stable } \\
\text { Internet connection should be } \\
\text { provided to facilitate the use of } \\
\text { Blackboard platform (P8) }\end{array}$ \\
\hline
\end{tabular}

Note: $P$ = Participants

As indicated in Table 2, the emergent themes suggest that challenges encountered by ICP students when using Blackboard Collaborate as a remote learning tool during the COVID-19 pandemic at College of Science and Arts in Unaizah, Qassim University, include insufficient technical knowledge and training, limited and poor internet connection, inability to upload and download large size files and problems with logging in password. These findings suggest that some students had challenges as a result of a lack of technical knowledge and training of how to use Blackboard Collaborate as a remote learning tool during the COVID-19 pandemic. However, in order to make advantage of the Blackboard Collaborate as a remote learning tool, students must first acquire the necessary technical knowledge and training to develop their technical skills. Furthermore, the students believe that these challenges can be overcome by providing ICP students with adequate knowledge, training and orientation on how to use Blackboard Collaborate more effectively. They also recommended that speed and stable Internet connection should be provided to facilitate the use of Blackboard platform as a learning tool. Furthermore, poor internet connectivity and accessibility cannot be neglected, as low-speed internet interrupts students' online activities and participation. Likewise, technical skill is critical because accessing and using online course content is primarily dependent on an individual's technical literacy and competence level. The inability to use learning tools, like Blackboard platform, effectively can be problematic, obstructing students' development and limiting their learning outcomes.

\section{DISCUSSION OF FINDINGS}

According to the findings of this study, ICP students encountered challenges in using Blackboard Collaborate as a remote learning tool during COVID-19 pandemic due to a lack of technological knowledge, training and technical problems such as losing logging in password and poor internet connectivity. Using Blackboard Collaborate, on the other hand, benefit ICP students in terms of online cooperative learning, flexible learning in a variety of ways other than face to face learning, having access to a wide range of information for academic purposes and ability to use technology effectively. The findings of this study are in line with Khafaga (2021) who found out that many students emphasized that Blackboard Collaborate improved their language and communicative competencies. The complete dependence on e-learning via Blackboard helps them improve their linguistic skills, particularly listening and speaking. Blackboard instruction allows them much time to access information, which in turn serves to develop their exposure to language via group conferencing and chatting that also proves useful in developing their communicative English (Khafaga 2021).

The findings of this study are also supported by studies on LMS acceptance and self-efficacy (Alshammari et al., 2016; Alshammari et al., 2018). They also claimed that technological and institutional aspects are some of the challenges that learners and teachers experience when implementing Blackboard learning. The findings indicate that the use of Blackboard application develops the self-learning which is important for the improvement of online learning process. Moreover, the findings of the study show that the learners were satisfied with using Blackboard Collaborate for learning. Consequently, instructors and syllabus designers are in a hard need to develop the content of the learning material to gain the benefits of using Blackboard Collaborate as a learning tool. Furthermore, the findings of this research, like those of previous researches, emphasize the importance of providing the contents in a user-friendly display, with relevant, clear instruction, and easy accessibility. (El Miedany, 2019; Heirdsfield et al., 2011).

According to the findings of this study, some students at College of Science and Arts in Unaizah, Qassim University encountered challenges because they have never used Blackboard platform before in their previous secondary schools. One of the participants says "... I have never used the Blackboard platform before at my secondary school" (P1). This view was repeated and confirmed by other two participants, the first of them stated, "I didn't have a Blackboard platform while I was a student in secondary school" (P3). The second asserted, "....I have never used Blackboard platform during my previous study years" (P15). These outcomes show that prior technological training and knowledge provide students with huge opportunities to engage with technology based online learning and improve their digital competence and technical literacy.

Through using Blackboard Collaborate as a remote learning tool, students not only need skills but also standards and practices on how to manage learning technologies such as Blackboard platform. As such, 
students require the competence to learn through the online environment and manipulate digital platforms such as Blackboard platform (Meyers et al., 2013). Despite the fact that some ICP students have prior technical knowledge of using Blackboard platform as a remote learning tool, there is a need for developing technical skills that may impact their utilization of Qassim university library data bases and other online materials and resources. In this respect, Warschauer (2007) debated that to face the current global challenges; institutions must equip learners with e-learning technical skills. This is because digital literacy becomes paramount as the e-learning facilities prove effective in developing positive learning outcomes (Hoic-Bozic et al., 2016). Some of the ICP students recommended that the Deanship of E-Learning and Distance Learning should organize extra technical training courses and orientation programs for new ICP students on the use of Blackboard platform and other learning facilities. A student states "the university should organize more technological training courses and more orientation programs for ICP new students" (P1). Digital learning aims to help students overcome learning problems and develop their skills (Prensky, 2003).

\section{IMPLICATIONS AND CONCLUSION}

This study explored the benefits and challenges of using Blackboard Collaborate as a remote learning tool among ICP students at College of Science and Arts in Unaizah, Qassim University, Saudi Arabia, during the Covid-19 pandemic. The study revealed that using Blackboard Collaborate platform as a remote learning tool helps the ICP students to enhance online cooperative learning, flexible learning in a variety of ways other than face to face learning, having access to a wide range of information for academic purposes and ability to use technology effectively. However, according to the findings of this study, ICP students confront some challenges related to insufficient technical knowledge and training, limited and poor internet connection, inability to upload and download large size files and problems with logging in password. These findings show that although ICP students of College of Science and Arts in Unaizah encountered challenges, they benefitted from using Blackboard platform as a remote learning tool during COVID-19 pandemic.

There is insufficient or lack of research addressing the benefits and challenges of using the Blackboard Collaborate platform as a remote learning tool among ICP students, particularly during the COVID-19 Pandemic. As a result, this study adds to the knowledge of how ICP students use the Blackboard platform as a remote learning tool, as well as the benefits and challenges they face when using it during the COVID-19 pandemic. These challenges can be overcome by providing technological training courses and technical orientation sessions for new ICP students on how to use the Blackboard Collaborate platform as a learning tool. This can be achieved through the Blackboard platform training courses held by the Qassim University Deanship of E-Learning and Distance Learning. This research is expected to benefit higher education institutions stakeholders in general and ICP students in particular. The scope of this qualitative study was confined to ICP students at College of Science and Arts in Unaizah, Qassim University, with a small sample size of participants. As a result, future study may use a mixed-methods approach to provide generalizable results.

\section{REFERENCE LIST}

Adams Becker, S., Cummins, M., Davis, A., Freeman, A., Hall Giesinger, C., \& Ananthanarayanan, V. 2017. NMC Horizon Report: 2017 Higher Education Edition. Austin, Texas: The New Media Consortium.

Al-Asmari, AM., \& Rabb Khan MS (2014). E-learning in Saudi Arabia: Past, present and future, Near and Middle Eastern Journal of Research in Education, 2014(2), 211.

http://dx.doi.org/10.5339/nmejre.2014.2.

Alelaiwi, A., \& Hossain, M. S. (2015). Evaluating and testing user interfaces for e-learning system: blackboard usability testing. Journal of Information Engineering and Applications, 5(1), 23-30.

AlHazizi, O. (2020, September 27). The problem of Blackboard and slowness of the Internet troubled university students. Alyoum Newspaper,17271. Retrieved from https://lym.news/a/6279509.

Ali, W. (2020). Online and remote learning in higher education institutes: A necessity in 
light of COVID-19 pandemic. Higher Education, 10 (3) .

Aljabre, A. (2012). An exploration of distance learning in Saudi Arabian universities: Current practices and future possibilities. International Journal of Business, Humanities and Technology, 2(2), 131- 137.

AlKarani, A. S., \& Al Thobaity, A. (2020). Medical Staff Members' Experiences with Blackboard at Taif University, Saudi Arabia. Journal of multidisciplinary healthcare, 13. 1629-1634.

https://doi.org/10.2147/JMDH.S287389.

Almaqtri, M. A. T. (2014). How effective is e-learning in teaching English?: A case study. Journal of Education and Human Development, 3(2), 647-669.

Almelhi, A. A. (2014). Effects on and predictability of computer-mediated glosses in reading comprehension of EFL college students. The Reading Matrix, 14(2), 65-77.

Al-Naibi, S. A., Madarsha, K. B., \& Ismail, N. A. (2015). Blackboard use by faculty members in the colleges of applied sciences in the Sultanate of Oman. International Journal for Innovation Education and Research, 3(4), 26-40.

Al-Nofaie, H. (2020). Saudi University Students' Perceptions towards Virtual Education During Covid-19 Pandemic: A Case Study of Language Learning via Blackboard. Arab World English Journal, 11 (3), 420. DOI: https://dx.doi.org/10.24093/awej/vol11no3.1.

Alshammari, S. H., Ali, M. B., \& Rosli, M. S. (2016). The Influences of Technical Support,

Self-Efficacy and Instructional Design on the Usage and Acceptance of LMS: A Comprehensive

Review. Turkish Online Journal of Educational Technology-TOJET, 15(2), 116-125.

Alshammari, S. H., Bilal Ali, M., \& Rosli, M. S. (2018). LMS, CMS and LCMS: The confusion among them. Science International, 30(3), 455-459.

Aslanian, C. B., \& Clinefelter, D. L. (2012). Online college students 2012: Comprehensive data on demands and preferences. Louisville, KY: The Learning House, Inc.

Alzahour, A. W. (2013). EFL students' perceptions of a blended learning environment: Advantages,

limitations and suggestions for improvement. English Language Teaching, 6(10), 95-110.

Blackboard, Inc. (n.d.). About us. Retrieved from http://www.blackboard.com/aboutus/index.aspx

Bransford, J. D., Brown, A., \& Cocking, R. (Eds.). (1999). How people learn: Mind brain,

experience and school. Washington, DC: National Academy Press.

Brooks, D. C. (2015). ECAR study of faculty and information technology. Research report.

Louisville, CO: ECAR. Retrieved from http://www.educause.edu/ecar

Chang, C. (2008). Faculty perceptions and utilization of a learning management system in higher education. Doctoral dissertation. Ohio University, USA.

Choy, D., Xiao, J., \& lliff, J. (2005). How can technology help improve the quality of Blackboard faculty training and encourage faculty to use Blackboard? In 2005 Annual proceedings-Orlando, Vol. 1, pp. 130.

Cohen, L., Manion, L., \& Morrison, K. (2007). Research Methods in Education. London and

New York: Routledge.

Creswell, J. W. (2012). Research design: Qualitative, quantitative and mixed-method approaches (2nd ed.). London: SAGE Publications

D'Silva, R., \& Reeder, K. (2005). Factors that influence faculty members' uptake and continued use of course management systems. British Journal of Educational Technology, 36(6), 1071-1073.

El Miedany, Y. (2019). e-Learning, Adaptive Learning and Mobile Learning Rheumatology Teaching (pp. 235-258): Springer. https://doi.org/10.1007/978-3-319-98213-7 13 
Fageeh, A., \& Mekheimer, M. (2013). Effects of blackboard on EFL academic writing and attitudes.

The JALTCALL Journal, 9(2),169-196.

Farooq, U. M., Alasmari, A., \& Javid, Z. C. (2012). A study of online English language teacher education programmes in distance education context in Pakistan. English Language Teaching, vol. 5(11), 91-103. http://dx.doi.org/10.5539/elt.v5n11p91

GarciaBotero, G., Questier, F., Cincinnato, S., He, T., \& Zhu, C. (2018). Acceptance and usage of mobile assisted language learning by higher education students. Journal of Computing in Higher Education, 30 (3), 426-451. 10.1007/s12528-018-9177-1.

Goss, J. D., \& Leinbach, T. R. (1996). Focus groups as alternative research practice: experience with transmigrants in Indonesia. Area, 28(2), 115-123.

Heirdsfield, A., Walker, S., Tambyah, M., \& Beutel, D. (2011). Blackboard as an online learning environment: What do teacher education students and staff think? Australian Journal of Teacher Education, 36(7), 1-16. http://dx.doi.org/10.14221/ajte.2011v36n7.4

Hoic-Bozic, N., Dlab, M. H., \& Mornar, V. (2015). Recommender system and web 2.0 tools to enhance a blended learning model. IEEE Transactions on Education, 59(1), 39-44.

doi: 10.1109/TE.2015.2427116

Ibrahim, L. K., Mohamed, A. G., Aldhafeeri, F. M., \& Alqdah, M. (2019). Faculty members' perceptions towards utilizing blackboard in teaching system at Hafr Al-Batin University, Saudi Arabia. Journal of Nursing Education and Practice, 9(5). https://doi.org/10.54 30/inep.v9n5p64

Jackson, P. (1998). Focus group interviews as a methodology. Nurse Researcher, 6(1), 72.

Jacob, S. M., \& Issac, B. (2008). Mobile technologies and its impact-an analysis in higher education context. International Journal of Interactive Mobile Technologies, 2(1).

Kashghari, B., \& Asseel, D. (2014). Collaboration and interactivity in EFL learning via blackboard collaborate: A pilot study. A paper presented at the International Conference ICT for Language Learning, 13-14, November 2014.

Kassop, M. (2003). Ten ways online education matches, or surpasses, face-to-face Learning. Kemp, A., Palmer, E., \& Strelan, P. (2019). A taxonomy of factors affecting attitudes towards educational technologies for use with technology acceptance models. British Journal Education Technology, 50 , 2394-2413. 10.1111/bjet.12833.

Khafaga, A.F. (2021). The perception of blackboard collaborate-based instruction by EFL majors/teachers amid COVID-19: A case study of Saudi universities . Journal of Language and Linguistic Studies, 17(Special Issue 2), 1160-1173.

Kitoo, S. M. (2020). Residential Faculty Members' Differential Use of Blackboard Tools: A Case Study. Liaw, S. S. (2008). Investigating students' perceived satisfaction, behavioural intention, and effectiveness of e-learning: A case study of the blackboard system. Computers and Education, 51(2), 864-873. http://dx.doi.org/10.1016/i.compedu.2007.09.005

Malikowski, S. R., Thompson, S., \& Theis, J. G. (2007). A model for research into course management systems: Bridging technology and learning theory. Journal of Educational Computing Research,36(2), 149-173. http://dx.doi.org/10.2190/1002-1T50-27G2-H3V7

Martin, F., Parker, M., \& Oyarzun, A. B. (2013). A case study on the adoption and use of synchronous virtual classrooms. The Electronic Journal of e-Learning, 11(2), 124-138. 
Proceedings of INTCESS 2022- 9th International Conference on Education \& Education of Social Sciences 17-18 January 2022- Online Conference

Maslamani, J. A. (2013). Potential integration of a computer-mediated communication platform into the Saudi EFL classroom: A synthetic review. International Journal of Humanities and Social Science, 3(15), 72-87.

McLafferty, I. (2004). Focus group interviews as a data collecting strategy. Journal of advanced nursing, 48(2), 187-194. doi: 10.1111/j.1365-2648.2004.03186.x

Meyers, E. M., Erickson, I., \& Small, R. V. (2013). Digital literacy and informal learning environments: an introduction. Learning, media, and technology, 38(4), 355-367.doi:

$10.1080 / 17439884.2013 .783597$

Mohsen, A. M., \& Shafeeq, P. C. (2014). EFL teachers' perceptions on blackboard applications. English Language Teaching, 7(11), 108-118.https://dx.doi.org/10.5539/elt.v7n11p108

Munoz, K. D., \& Van Duzer, J. (2005). Blackboard vs. Moodle: A comparison of satisfaction

with online teaching and learning tools. Available at: http://www.immagic.com/eLibrary/ARCHIVES/GENERAL/HSU CAUS/H050215M.pdf

Muhammad, A., Shaikh, A., Naveed, Q. N., \& Qureshi, M. R. N. (2020). Factors Affecting Academic Integrity in E-Learning of Saudi Arabian Universities. An Investigation Using Delphi and AHP. IEEE Access, 8, 16259-16268. https://doi.org/10.1109/access.2020.2967499

O'Reilly, K. (2005). Key concepts in ethnography. New York: SAGE Publications.

Palloff, R. M. \& Pratt, K. (2013). Lessons from the Virtual Classroom (2nd Ed). San Francisco,

CA: Jossey-Bass.

Prensky, M. (2003). Digital game-based learning. Computers in Entertainment (CIE), 1(1), 21 -

22. doi: https://doi.org/10.1145/950566

Shih, Y., Lin, Y., \& Yang, M. (2007). The development of an online virtual English classroom: VEC3D. Journal of Information Technology and Applications, 2(2), 61-68.

Thalheimer, W. (2008, May). Providing Learners with Feedback—Part 1: Research-based recommendations for training, education, and e-learning. Retrieved January 9, 2021, from http://www.worklearning.com/catalog/

UNESCO. (2020) COVID-19 educational disruption and response. Available online: https://en.unesco.org/covid19/educationresponse. (Accessed on January 3rd 2021)

World Health Organization (2020): Coronavirus disease (COVID-2019) situation reports. Available online: https://www.who.int/emergencies/diseases/novel-coronavirus-2019/situation-reports (Accessed on January 15th 2021)

Xin, H., Kempland, M., \& Blankson, F. H. (2015). Adaptability and replicability of webfacilitated, hybrid, and online learning in an undergraduate exercise psychology course. Turkish online Journal of Educational Technology-TOJET, 14(1), 19-30. 